\title{
FOREIGN LANGUAGE ANXIETY IN STUDENT LEARNING
}

\author{
Asta Lileikienė, Lina Danilevičienė \\ Lithuanian Sports University, Kaunas, Lithuania
}

\begin{abstract}
Background. Anxiety includes uncomfortable feelings when learning or using the new language. It continues to exist in the university foreign language classroom as well. A number of foreign language students report feeling anxious about language learning. Research aim was to investigate the foreign language anxiety (in our case, English as a foreign language, EFL) in the classroom context at tertiary level in relation to its effect on foreign language acquisition as well as to design recommendations of how to reduce or exclude foreign language anxiety from the university foreign language classroom.

Methods. The Foreign Language Classroom Anxiety Scale developed by E. K. Horwitz, M. B. Horwitz, and Cope (1986) was used. The questionnaire consisted of 5 statements about the respondents' general background and 33 statements which were evaluated on the Likert scale from 1 to 5 by the research participants. The research sample involved 200 first and second year students of Lithuanian Sports University.

Results. The research analysis revealed that the respondents generally felt anxious speaking in the language class, making mistakes and being corrected by the teacher, worrying about the consequences of failing foreign language class and speaking with native speakers. The correlation between the students' level of knowledge and their feeling of anxiety was established: students of lower level (A2 and B1) tended to feel higher levels of anxiety. Moreover, female participants of this study exhibited higher levels of foreign language anxiety.

Conclusions. Foreign language anxiety proved to be a powerful predictor for demotivation in foreign language learning and impeded the acquisition of foreign languages. The research analysis revealed that the majority of younger respondents demonstrated a higher degree of anxiety. The more mature the students were, the more confident they felt in EFL classes. It was found that female students felt higher level of anxiety in learning English as a foreign language than male students. They were more inclined to hesitate and felt anxious in the language classroom, while male undergraduates were more confident and had a greater ability to cope with the feelings of anxiety and nervousness. Students with higher knowledge of English language (level B2) showed lower levels of anxiety and felt more confident in language class. A large number of failures was observed at the pre-intermediate and lower intermediate (A2/B1) levels. Therefore, the learners with high anxiety often got low achievement and low achievement made them more anxious about learning.
\end{abstract}

Keywords: anxiety, foreign language acquisition, higher education.

\section{INTRODUCTION}

A nxiety is defined as a subjective feeling of tension, apprehension, nervousness, and worry usually associated with an arousal of autonomic nervous system. A feeling of nervousness associated with foreign language learning is termed as foreign language anxiety (FLA). Horwitz et al. (1986) were the first to conceptualize FLA as a unique type of anxiety specific to foreign language learning. E. K. Horwitz, M. B. Horwitz \& Cope (1991) view FLA as a distinct complex of self-perceptions, beliefs, feelings, and behaviours related to classroom language learning arising from the uniqueness of the language learning process. MacIntyre and Gardner (1998) conceive of FLA as the worry and negative emotional reaction aroused when learning or using 
a second language. There is a considerable amount of research indicating that foreign language anxiety (FLA) is a reality for many students and is not merely an abstract construct studied by theorists or by researchers under laboratory on induced-anxiety conditions. It continues to exist in the university foreign language classrooms. Second and foreign language researchers and linguists have long been trying to associate anxiety with language learning, in general, as well as in a classroom situation. They argue that specific classroom situations provoke anxiety during different stages of the language learning process. Thus, foreign language anxiety is a powerful predictor for demotivation in foreign language achievement which means that FLA has debilitating effects on learners' achievements/ scores. Other authors (Ghadirzadeh, Hashtroudi, \& Shokri, 2012) also point out that in order to make an impact on motivation in EFL (English as a Foreign Language) learning it is important to recognize and remove anxiety which usually reinforces demotivation in foreign language learning and hence leads to undesired learning outcomes. Moreover, it was confirmed that the unwillingness to study a foreign language or even failure in meeting the requirements of the university program was determined by anxiety as the most demotivating factor in learning foreign language at the university level (Lileikienè \& Danilevičienè, 2015). Thus, the research aim was to investigate the foreign language anxiety in the classroom context in relation to its effect on foreign language acquisition as well as to design recommendations of how

\section{METHODS}

The research was conducted in JanuaryFebruary of 2016. The Foreign Language Classroom Anxiety Scale (FLCAS) developed by Horwitz et al. (1986) was used. The FLCAS has been used in studies extensively over the past 30 years and has facilitated a tremendous development in the research into FL classroom anxiety. The questionnaire consisted of 5 statements about the respondents' general background and 33 statements which were evaluated on the Likert scale from 1 to 5 (the 5-point Likert Scale: $1=$ Strongly Disagree, $2=$ Disagree, $3=$ Neither Agree nor Disagree, $4=$ Agree, $5=$ Strongly Agree) by the research participants. The research sample involved 200 first and second year undergraduate students of Lithuanian Sports University $(58.5 \%$ females and $41.5 \%$ males), studying in Physical Activity and
Public Health, Sports Coaching, Physiotherapy, Adapted Physical Activity, Physical Education and Sport, Sports Industries, Sports Recreation and Tourism study programs.

The FLCAS was translated into Lithuanian by an official translator and edited by the researchers so as to carry the meaning of the original instrument. Subsequently the Lithuanian version was given to two experienced EFL teachers, who are native speakers of Lithuanian, to translate back into English to confirm that the meaning had not been altered.

The data was analyzed using the SPSS version 22 statistics package. Data is presented as frequencies or absolute values. Associations between categorical variables were determined using Chi square test.

The research sample comprised 3 age groups (18-20 years old (75.5\%), 21-23 years old (22\%) and 24 and more years old (2.5\%) of whom 56.5\% lived in the city, $30.5 \%$ - in town and $13 \%$ - in village.

\section{RESULTS}

The research results demonstrated that age was statistically significantly related with the students' attitude and anxiety level while studying foreign languages. In response to the statement 'I never feel quite sure of myself when speaking in my foreign language class' the group aged 18-20 years old reported the lack of confidence $(80 \%)$ whereas $25 \%$ of 24 and more years old students did not feel anxious and were self-confident, when $\chi^{2}=26.69$, $p=.001$ (Figure 1).

Older students demonstrated higher levels of intrinsic motivation as well. Younger students were afraid of being laughed at or corrected by a teacher. $80 \%$ of the $18-20$-year-old respondents thought about the things that were not related to the course while older respondents felt more involved in the course $\left(\chi^{2}=14.72, p=.006\right)$. The statistically significant finding was made that younger students worried about consequences of failing in the language class more $(76.7 \%)$ while the $21-23$-yearold students felt more relaxed about their course results (7\%) and only $3.3 \%$ of 24 -year-olds worried about failing consequences. $\left(\chi^{2}=17.29, p=.027\right)$.

The study revealed that students who were eager to learn a foreign language and would not worry about taking more language classes lived in the city (48.4\%), in town $(29 \%)$ and students living in a village demonstrated the lower level 
of intrinsic motivation and a wish to develop themselves learning languages $\left(\chi^{2}=17.19, p=\right.$ $.028)$. The city residents were likely to feel more at ease during tests $(75 \%)$ and felt more comfortable around native speakers (city $-53.8 \%$, town $-23.1 \%$ and village $-23.1 \% ; \chi^{2}=21.51, p=.006$ ).

Female students panicked to speak in front of others and got nervous when asked questions without preparation. In addition, female students did not feel self-confident in the foreign language class when speaking (73.7\%) as compared to their male counterparts $(26.3 \%)\left(\chi^{2}=16.65, p=.002\right)$. Thus, the majority of the questioned male students indicated the high level of confidence when they spoke in the foreign language class $(75 \%$ of the male students strongly disagreed with the statement 'I never feel sure of myself while speaking in the foreign language classroom', when $\chi^{2}=16.65, p=$ .002) (Figure 2).

Although female students felt well prepared, they were anxious and embarrassed when asked to volunteer answers in class (81.5\%). Whereas male students felt confident while they spoke in the foreign language class (only 18.2\% of male students strongly agreed with the statement 'It embarrasses me to volunteer answers in my language class'). They did not think that other students spoke better $\left(87.5 \% ; \chi^{2}=33.07\right)$ or that other students would laugh at them making mistakes $\left(68.2 \% ; \chi^{2}=28.92\right)$, when $p<.05$.
Figure 1. Participants' level of self-confidence while speaking in the foreign language class with respect to age

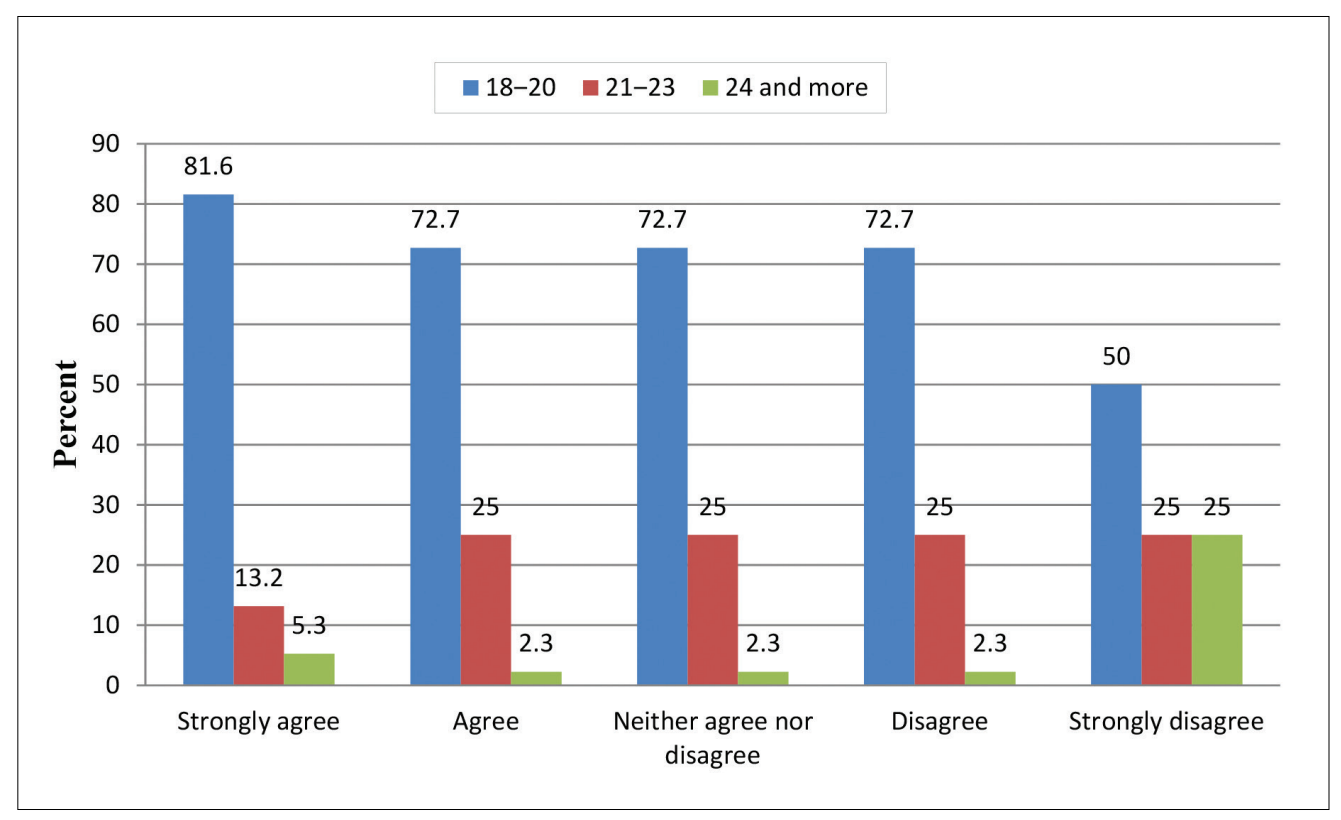

Figure 2. Participants' level of self-confidence while speaking in the foreign language class with respect to gender

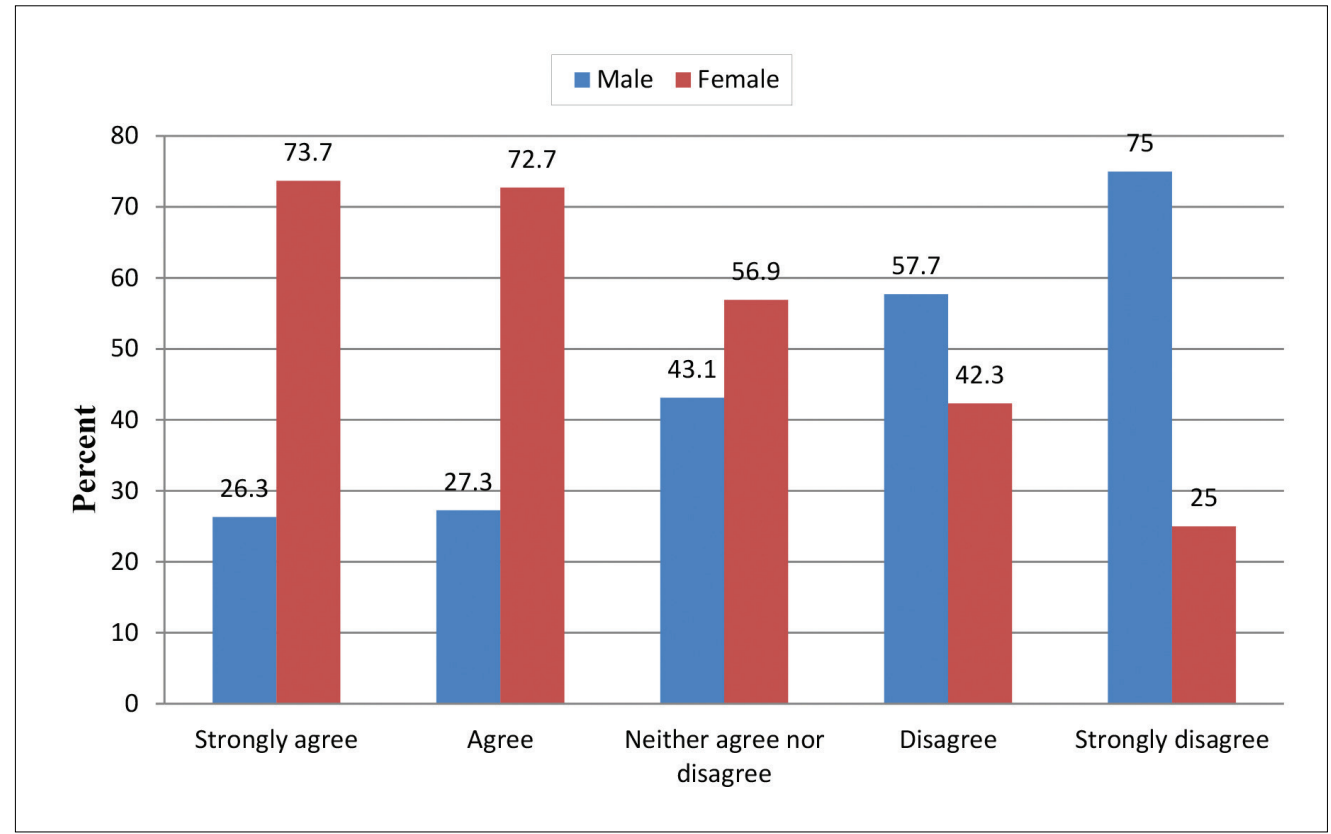




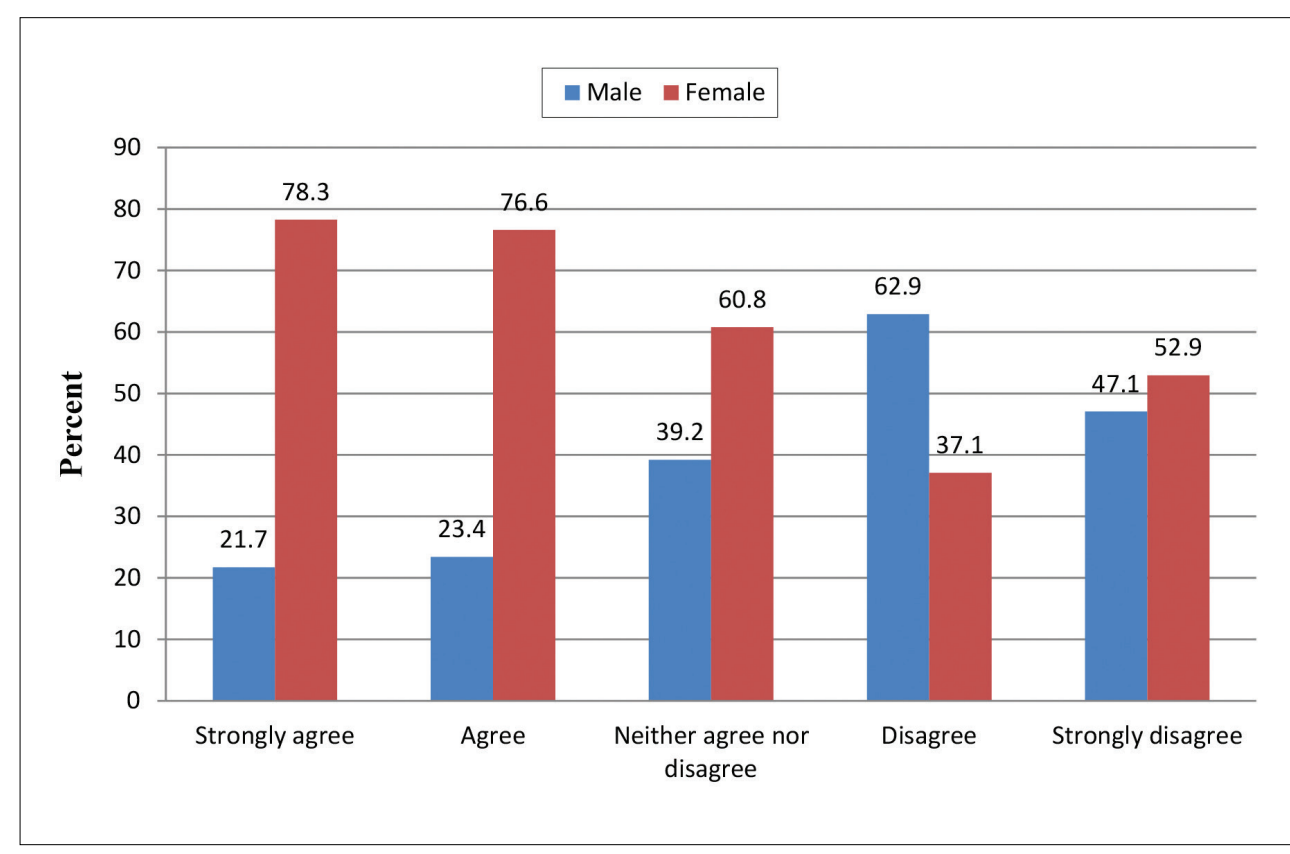

Figure 3. Participants' level of anxiety in the foreign language class as compared to other classes with respect to gender

The statistically significant findings in Figure 3 demonstrate that the majority of female respondents felt tense and anxious in the language class more than in other classes $(78.3 \%)$ as compared to male students $\left(21.7 \%, \chi^{2}=22.06, p<.05\right)$.

Finally, the investigated female students most frequently felt like not going to the foreign language class $(77.3 \%$ of females and $22.7 \%$ of males, when $\chi^{2}=10.17, p=.038$ ). Consequently, female participants experienced even physiological reactions in the class (heart pounding $\left(\chi^{2}=36.25\right.$, $p<.05$ and trembling $\left(\chi^{2}=12.28, p=.0015\right)$ more than male students.

A statistically significant correlation was established between the students' English knowledge level and their confusion before a language test. Only $10 \%$ of the participants with A2 level got more confused the more they studied for a language test, whereas $50 \%$ of them with B1 level and $40 \%$ with B2 level got confused the more they studied for a language test $\left(\chi^{2}=44.23, p<.05\right)$.

Students with B1 level (55.1\%) felt most of all overwhelmed by the number of rules they had to learn, whereas $32.7 \%$ of students with B2 level and $10.2 \%$ with A2 level felt less anxious about it $\left(\chi^{2}=\right.$ $28.92, p=.024)$.

More than a half of the participants with B1 (52.4\%) got nervous when they did not understand every word the teacher said, while $23.8 \%$ of students with A2 and B2 level worried about that $\left(\chi^{2}=36.72, p=.002\right)$.

However, the research analysis revealed that irrespective of the level of English competence about one third of the students in level A2 (26\%) and level B2 (28\%) started to panic when they had to speak without preparation in language class, while students with $\mathrm{B} 1$ level panicked the most $46 \%\left(\chi^{2}=30.25, p=.017\right)$.

Moreover, regardless of the level of the English language knowledge, about one third of students in all levels of language competence felt more tense and nervous in foreign language class than in any other classes: A2 - 30.4\%; B1 - 39.1\%; B2 - 30.4\% $\left(\chi^{2}=26.88, p=.043\right)$ (Figure 4).

The duration of studying English was taken as a variable in researching its relationship with students' anxiety and their achievements. In Lithuania students usually study English as the first foreign language for 10-12 years on average. An important finding of the research was that the longer students studied English the less they were afraid of making mistakes $\left(\chi^{2}=77.90, p=.012\right)$, as well as another finding that the longer students studied English the more they felt comfortable around native speakers. As many as $37.9 \%$ of the research participants (12 years of studies) would feel comfortable around native speakers of the foreign language $\left(\chi^{2}=82.85, p=.004\right)$.

Nevertheless, irrespective of the duration of their studies of English about one fifth of the students felt embarrassed to volunteer in English classes: 10 years of studies $-18.2 \%$; 12 years of studies $-27.3 \%\left(\chi^{2}=71.04, p=.041\right)$. 
Figure 4. Participants' level of anxiety in the foreign language class as compared to other classes with respect to their foreign language level

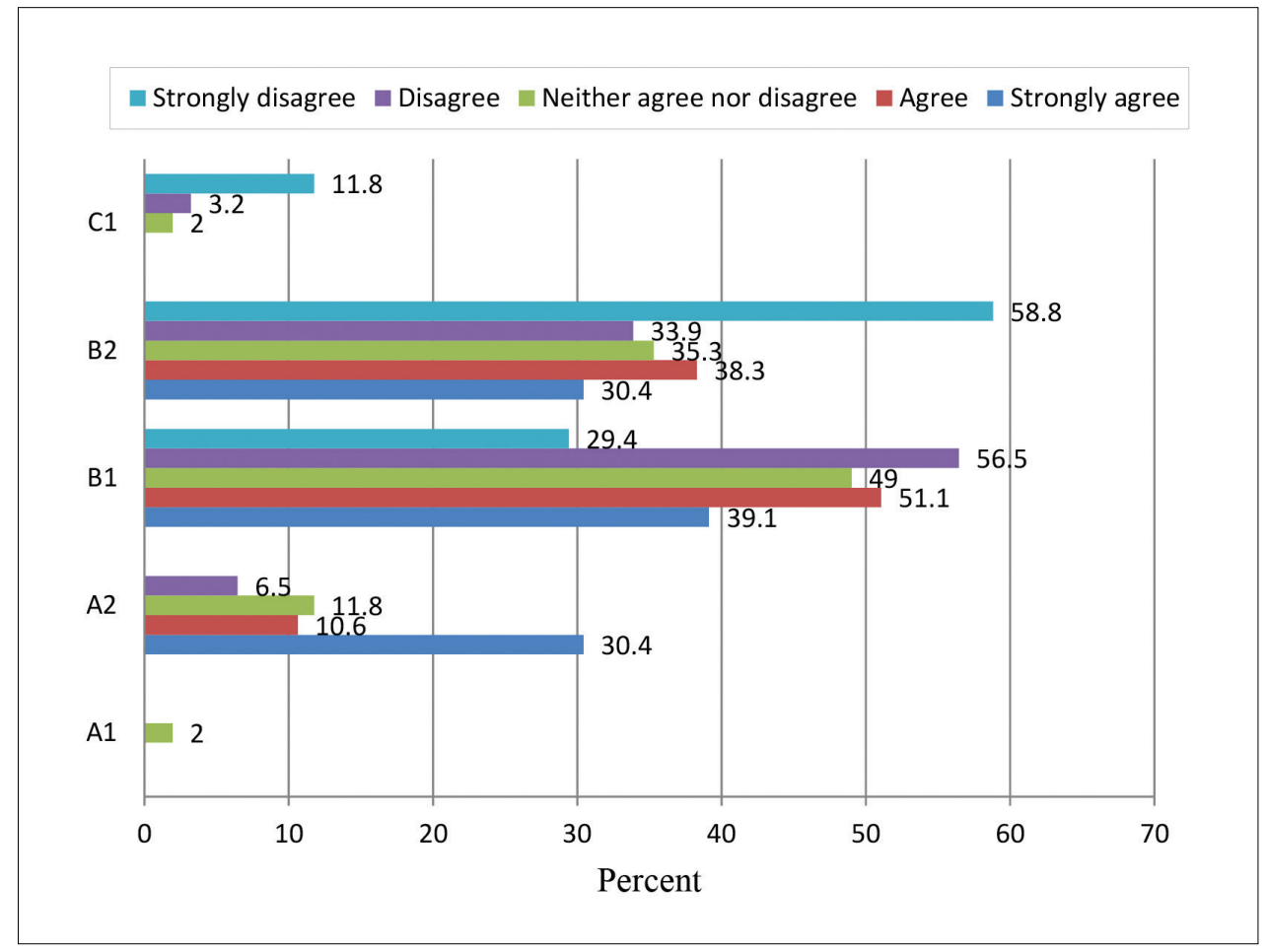

\section{DISCUSSION}

Horwitz et al. (1991) identified the possible causes of FLA as communication apprehension, test anxiety and fear of negative evaluation. Chen and Chang (2004) suggest that in addition to task difficulty, factors such as teachers' attitude and evaluation, teacher-students interactions in class, parents' expectations, classmates' attitudes, students' own achievements are the potential sources of students' foreign language anxiety. The research analysis revealed that the respondents generally felt anxious speaking in the language class, making mistakes and being corrected by the teacher, worrying about the consequences of failing in a foreign language class and speaking with native speakers, thinking that other students spoke better than they did, and being afraid of being laughed at, etc.

The research focused on the investigation of the foreign language anxiety in the classroom context in relation to its effect on foreign language acquisition with respect to age. It was proved that anxiety was also closely correlated with age (Bailey, Onwuegbuzie, \& Daley, 2000) and motivation (Yan \& Horwitz, 2008). Consequently, the research showed that the level of anxiety in class statistically significantly decreased as students got older, mature, built more self-esteem and developed as personalities.
Similarly to the earlier research performed by Öztürk and Gürbüz (2013) on gender and language anxiety, the analysis of the foreign language anxiety in the classroom context in relation to its effect on foreign language acquisition with respect to gender proved that female participants of the present study tended to exhibit significantly higher levels of foreign language anxiety as well. The previous research demonstrated that anxiety was also closely correlated with learning difficulties (Chen \& Chang, 2004). The findings of this study showed that students with higher knowledge of English language (level B2) were less frightened and did not feel anxious when they did not understand their teacher. They also felt at ease during tests, felt more confident when speaking in English language class and worried less about getting left behind.

Despite the foreign language knowledge level, students still felt anxious in their foreign language classroom, which proved the conclusions made in many other research that anxiety in a foreign language class is not a rare phenomenon referring to the research by Suleimenova (2013) who, correspondingly, found that the majority of students still experienced uneasiness and anxiety while they spoke in the foreign language.

It can be concluded that, in agreement with Riasati's (2011) study, foreign language anxiety still persists in the language learning process and, consequently, negatively affects students' performance in the foreign language classroom. 


\section{CONCLUSIONS}

Foreign language anxiety proved to be a powerful predictor for demotivation in foreign language learning and impeded acquisition of foreign languages. The research analysis revealed that the majority of younger respondents demonstrated a higher degree of foreign language anxiety. The more mature the students were, the more confident they felt in foreign language classes. It is also found that female students felt higher level of anxiety in learning English as a foreign language than male students. They were more inclined to hesitate and feel anxious in the language classroom. This result shows that male undergraduates were more confident and had a greater ability to learn a new language and cope with the feelings of anxiety and nervousness.

Students with higher knowledge of English language (level B2) showed lower level of anxiety and felt more confident in language class. A large number of failures were observed at the preintermediate (A2) level. Therefore, the learners with high anxiety often got low achievement and low achievement made them more anxious about learning.

Keeping in mind the findings of the study and for the purpose of improving students' performance in English, it is necessary for language teachers as well as learners to consider measures to facilitate anxiety levels. Establishing realistic and achievable goals, building a relaxing classroom environment, taking into consideration language learning experiences and feelings, providing assistance, approving and praising learners often, etc., have been recommended to be effective in reducing anxiety levels.. Therefore, these measures might help to boost self-esteem and promote intrinsic motivation of students paying more attention to the building and enhancing their personalities' development to achieve better results in the foreign language classroom and, thus, in the overall goal of studies in the student learning process.

\section{REFERENCES}

Bailey, P., Onwuegbuzie, A. J., \& Daley, C. E. (2000). Correlates of anxiety at three stages of the foreign language learning process. Journal of Language and Social Psychology, 19(4), 474-490. doi: 10.1177/0261927X00019004005

Chen, T. U. \& Chang, G. Y. (2004). The relationship between foreign language anxiety and learning difficulties. Foreign Language Annals, 37(2), 279-289. doi: U0026-0107201214482600

Ghadirzadeh, R., Hashtroudi, F. P., \& Shokri, O. (2012). Demotivating factors for English language learning among university students. Journal of Social Sciences, $8(2), 189-195$. Retrieved from http://thescipub.com/ PDF/jssp.2012.189.195.pdf

Horwitz, E. K., Horwitz, M. B., \& Cope, J. (1986). Foreign language classroom anxiety. The Modern Language Journal, 70(2), 125-132. Retrieved from http://www.jstor.org/stable/327317

Horwitz, M. B., Horwitz, E. K., \& Cope, J. (1991). Foreign language classroom anxiety. In E. K. Horwitz \& D. J. Young (Eds.), Language anxiety: From theory and research to classroom implications. Englewood Cliffs, New Jersey: Prentice Hall.

Lileikienè, A. \& Danilevičienè, L. (2015). Motivational variables in foreign language learning (pp. 56-61).
In Applied Research in Studies and Practice, No. 11. Panevėžys College.

MacIntyre, P. D. \& Gardner R. C. (1998). Anxiety and second language learning: Towards a theoretical clarification. In E. K. Horwitz \& D. J. Young (Eds.), Language anxiety: From theory and research to classroom implications (pp. 41-54). Englewood Cliffs, New Jersey: Prentice Hall. Öztürk, G. \& Gürbüz, N. (2013). The impact of gender on foreign language speaking anxiety and motivation. Procedia - Social and Behavioral Sciences, 70, 654-665. doi:10.1016/j. sbspro.2013.01.106

Riasati, M. J. (2011). Language learning anxiety from EFL learner's perspective. Middle-East Journal of Scientific Research 7(6), 907-914. Retrieved from http:// www.idosi.org/mejsr/mejsr7(6)11/13.pdf

Suleimenova, Z. (2013). Speaking anxiety in a foreign language classroom in Kazakhstan. Procedia - Social and Behavioral Sciences, 93, 1860-1868. doi:10.1016/j. sbspro.2013.10.131

Yan, J. X. \& Horwitz, E. K. (2008). Learners' perceptions of how anxiety interacts with personal and instructional factors to influence their achievement in English: A qualitative analysis of EFL learners in China. Language Learning, 58(1), 151-183. doi: 10.1111/j.14679922.2007.00437.99999 